\title{
The Aesthetic Study of Traditional Cloth of North Sumatera
}

\author{
Khairunnisa Butar-Butar \\ Departemen of Magister Desain \\ Universitas Komputer Indonesia \\ Bandung, Indonesia \\ d.power2@yahoo.co.id
}

\begin{abstract}
This scientific work was intended for to know about process of Ulos Batak, the philosophical, the effort of society in maintain the origanility of Ulos Batak and conserve to using in scope of tradition. By used descriptive analysis method with main source is ulos weaver and Batak's societies in Medan City, Samosir Island in North Sumatera Province and Bandung City. The use of gedogan loom is still found and preserve. The result of field search, in both location there are some equality, such as process of stanning, manggatip, mangunggas, martonun, ect. The weaving skills is still awake because any effort to teach from ancestor and from parent to their children especially to girls. For the majority, the activities of Batak are still very well preserve. But for minority, there is a reduction of enthusiasm especially the younger generation. With the reason that activity relatively low and boring and no understanding of meaning. Many activity we can do for preserve our culture and the heritage, we will be following ritual activities, proudly to use traditional cloth, learn and understand the meaning and process of traditional cloth. In education,we can insert the skill of weaving in the school curriculum, such as Ulos Batak weaving in North Sumatera with majority of Batak society. In the world of design, it can used with develop the physical, ornament and product development by incorporating elements of Ulos and Batak's culture.
\end{abstract}

Keywords-Ulos Batak, backstraploom, culture, aesthetic form, symbolic meaning

\section{INTRODUCTION}

To find out the culture of the country or region one of the ways that can be learned the traditional cloth. Each region has a type of wastra / traditional cloth. Wastra comes from Sanskrit (the word absorption) which means a piece of cloth that is traditionally made. Indonesia's natural wealth is one of the supporters of the creation of wastra. One of them is cotton plants which are the basic ingredients for making traditional fabrics. Aesthetic is the things like the quality of the beauty of the object, also the power of impulses, and the aesthetic experience of the creator [1]. But aesthetic can also tell about how the process of the object.

The research itself has been conducted about textile design process by Rachel Studd, this part has crusial role to creating innovative and attractive product, but little is known about how designer work in practice[2]. In another study, the analysis of Ulos Parompa Sadum which was viewed from the form, ornament, color, function and meaning in Sipirok Subdistrict, South Tapanuli[3]. Which shows that the function of ulos in the customs of the south Tapanuli community is very important and there are also a variety of ornaments that adorn every part of ulos cloth that has own color and meaning. Discussed the symbolic meaning of cultural communication in the traditional marriage ceremony of the Batak toba tribe in Pekanbaru[4]. Which describes physical objects including Ulos, social objects in customary marriage activities that have meaning. The other research about semiotics analysis on color symbols in Tobanese Batak Ulos by Yose Yulius Situmorang[5]. In her research, the writer wants to identify color in ulos and its meaning. There are nine ulos to be exposed. In Tobanese Batak culture, there are three color which are most dominant, they are white symbolizes truth, red symbolizes bravery and black symbolizes mysticism. It can be concluded that color is very important in Batak's life . Muhammad Takari in her journal, told aboud Ulos and of a kind in Bataknese culture north Sumatera. He had explained about meanings, functions and technology from Ulos Batak[6].

Because none of the above studies discussed the process of making Ulos Batak (gedogan / traditional techniques), the meaning contained in the Ulos Batak type and the effort to preserve the Ulos Batak weaving within the customary sphere. Then author did a research about that

The purpose of this study was to finded out the process of making ulos with gedogan techniques, knowed the philosophical Ulos Batak and the effort to maintain the weaving of Ulos Batak in the customary sphere. To support this research the author uses descriptive qualitative methods with a narrative approach. In hopes of increasing knowledge about textile science, traditional Indonesian weaving and fabric processes.

\section{METHOD}

This research used descriptive qualitative method. By explaining the findings in the field and explained by a narrative approach that is by investigating the lives of individuals or groups and researchers retelling in narrative chronology. Data sources were obtained from interviews, findings in the field and artifacts (Ulos Batak). Data sources used were interviews with weaver and Batak communities, collections of literature and Ulos Batak. Research locations are Samosir Island, Medan City and Bandung City. Implementation time was March - June 2018.

\section{RESULTS}

Basically, making Ulos Batak with gedogan weaving is the same as making other traditional fabrics such as songket. The use of ulos that must follow the rules becomes one of the 
uniqueness of the Batak tribe. In journal, the customary marriage activities of the Batak Tribe must follow the rules with the meaning that must be followed, which is represented in physical form, food and speech [4].

In two research locations, the author talked about the effort to preserve the Batak Ulos weaving. The informant said that they had tried to give knowledge to girls by introducing and teach weaving early. It will be a separate decision for children to continue these skills or learn other things outside the village. Besides that, other informant said that the activity of Martonun was the duty of women, as Boru Batak who else would defend this Ulos Batak if we don't, who will descendants of the Batak tribe.

Efforts to preserve the Ulos Batak have also been carried out by parents and Batak people, especially in the area of tradition. The activities are still seen to be carried out. Basically humans will experience three main phases in life, namely birth, marriage and death. Each of these phases of life contains rituals or customary procedures that will be carried out.

Ulos, is not only a long cloth but has symbolic meaning in the form of prayer, hope and blessing. For example in giving Ulos Mangiring to newborn children, especially in the first child, there are blessings, prayers and hopes for the child to be a useful human being and can protect his younger siblings by giving the best examples. Muhammad Irvan also said that in the Parompa Sadun ulos there were many ornaments and colors which meant the traditional customary philosophy in the South Tapanuli area. And every kinds of Ulos Batak have a meaning. It can be a hope, blessing from people who give.

The implementation of Batak tradition activities is still clearly visible, especially in the majority of the population, in contrast to the minority Batak community, there is little scarcity. Other problems of the younger generation who should preserve ancestral traditions seem less enthusiastic in carrying out this activity. Several reasons can be concluded due to lack of knowledge about customs, relatively long and contemporary activities that are more pleasant than traditional activities that seem old-fashioned.

\section{DISCUSSION}

After doing the steps in research about the Ulos Batak weaving in several locations. Information is obtained based on previous research objectives.

Sugiarto Dakung say in her book, Ulos is the result of Batak civilization. The beginning of ulos was everyday clothing before the entry of western civilization [7]. "Ulos is a Batak woven fabric in the shape of a shawl, with a certain length and width". The length and width of the Ulos fabric is adjusted to its usage, which is to be wrapped around the head (dililithon), drained on one or two shoulders (sampe-sampe atau dihadang), as a sarong (diabithon) and tightly attached to the waist ".

Culture is a form of effort and results man to maintain his life in nature reality with the power of thought [8].Culture is all things that humans do based on habits that have been inherited from their ancestors, both related to humans and humans and also humans with nature.

After conducting dialogues and searching about Ulos, several areas were found, especially in North Sumatra Province which still produce Ulos, both traditionally and with more modern tools. Like Medan City, Pematang Siantar City, Tarutung, Kabanjahe, Samosir Island and several other areas.

\section{A. Weaving process of Ulos Batak}

Hutaraja, Lumban Suhi-Suhi Toruan Village, Panguruan District, Samosir Regency, North Sumatra. It is a village that still preserves and maintains traditional weaving techniques (staining, mangunggas, mansorha, martonun,).

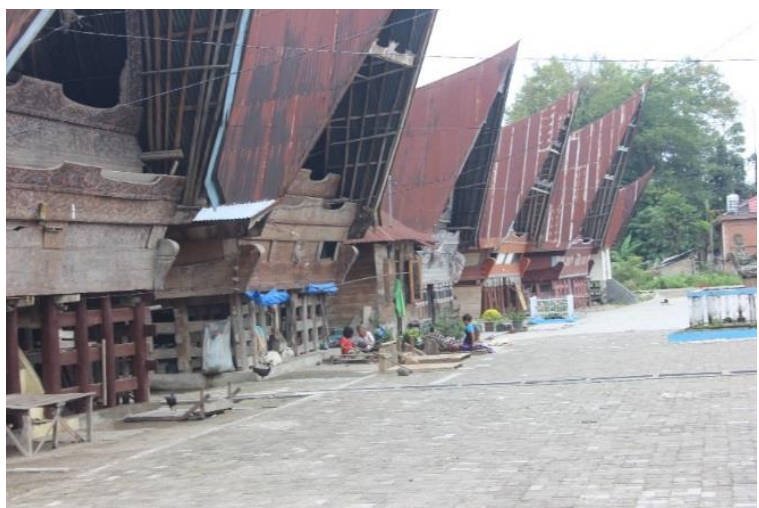

Fig. 1. Hutaraja, Lumban Suhi-Suhi Toruan Village, Pangururuan district, Samosir Regency, North Sumatera

Spinning cotton in to yarn and coloring. The process of spinning cotton into yarn is rarely done alone by weavers. Weaver get or buy rolls of yarn from toke (suppliers and collectors) both white and colored. Based on the narrative of toke, the yarn comes from Majalaya, West Java. The coloring used is with natural dyes (leaves and roots) and with artificial coloring.

Gatip (manggatip). It is special design founded on the thread, part of the coloring process with bind the thread part.

Pangunggasan atau mangunggas. It is done by making rice porridge and can be added to celery or pandan leaves for applied to the thread. This process used palm fiber (ijuk) in figure 2. The goal is to make the thread strong, decompose neatly and shiny. It is carried out in two ways, namely 'mengkanji', dipping a roll of yarn in a solution of water and starch.

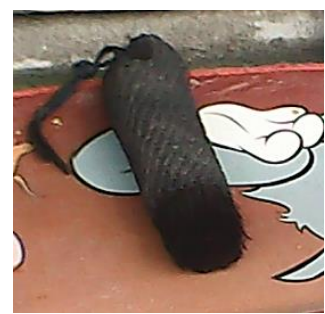

Fig. 2. palm Fiber 'Ijuk' (tool for mangunggas / pangunggasan) 


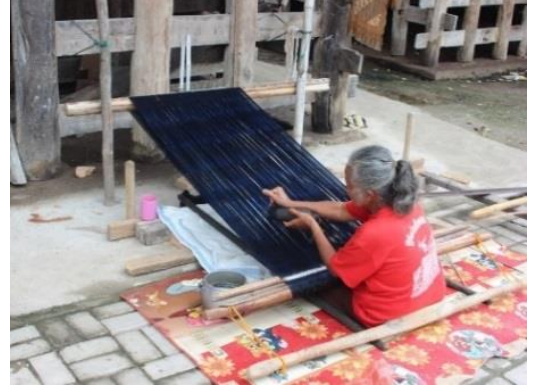

Fig. 3. mangunggas process in Hutaraja, Lumban Suhi-Suhi Toruan village, Pangururuan district, Samosir Regency, North Sumatera

Pangkulhul atau makkulhul. In figure 4, a women is tidying up the yarn by rolling it using a tool called sorha. This process called makkulhul.

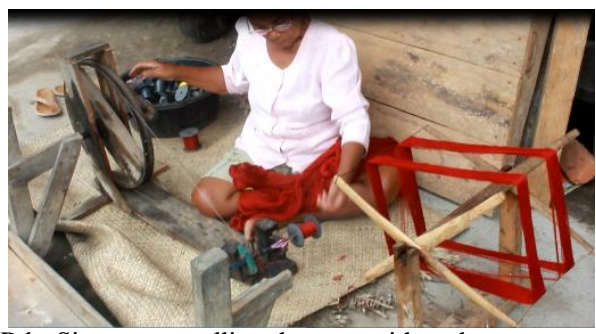

Fig. 4. Op. R br Simarmata, rolling the yarn with sorha

Mangani. Mangani is the process of thread stranding in the anian tool, which is the wooden beam above which is attached / placed by a short stick as an anian foundation. The yarn will be arranged according to the ulos size and based on the calculation of the number of sheets of yarn according to the design and color composition of Ulos to be produced. This is the initial process of weaving.

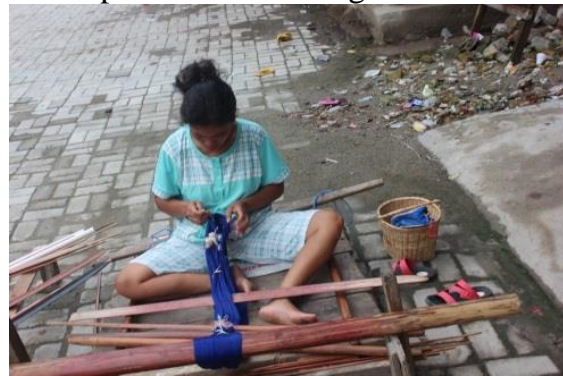

Fig. 5. mangani process

Martonun. Martonun is the process after the yarn is arranged. Partonun is a term for people weaving. At figure 6 is a weaver with loom.

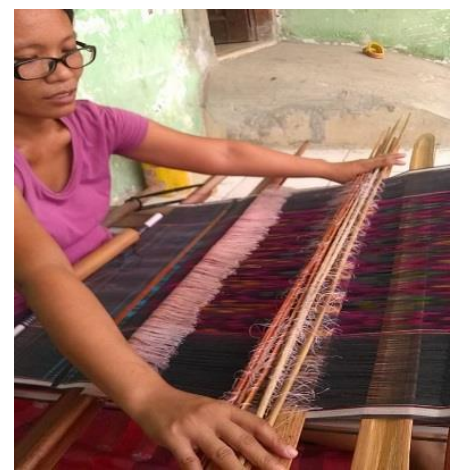

Fig. 6. Mama Nico, A weaver from Medan city do 'martonun'
Final completion. The process of finishing both ends of Ulos, with three methods that can be used, namely sewing sortali, sewing ribbon or lace and border sewing techniques.

\section{B. The tools used to weave Ulos Batak (Gedogan)}

In the weaving work of ulos (martonun) there are several tools used, it will be explained below. It can see in figure 7 .

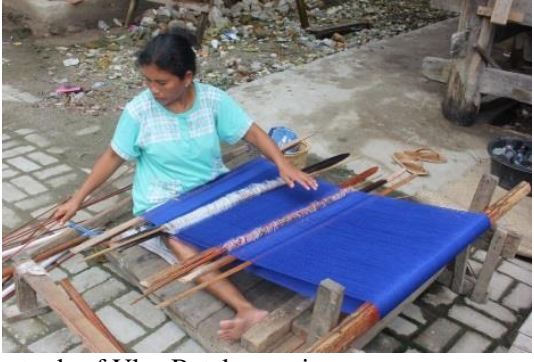

Fig. 7. weaving tools of Ulos Batak weaving

Anian. In figure 8 is anian, it is a place / wood to string yarn before weaving.

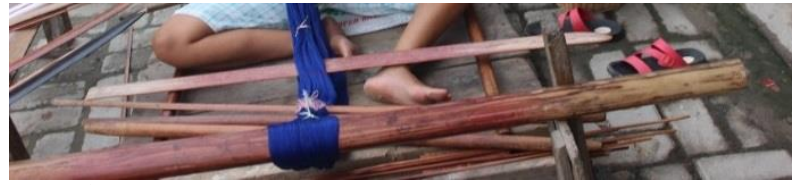

Fig. 8. Anian

Pamunggung / tundalan. Tundalan serves as a back / hip back support of the weaver. On the right side of the rope tied to the loom.

Pagabe. Pagebe, a wood which functions as a thread holder and linking the 'tundalan'. See in figure 9.

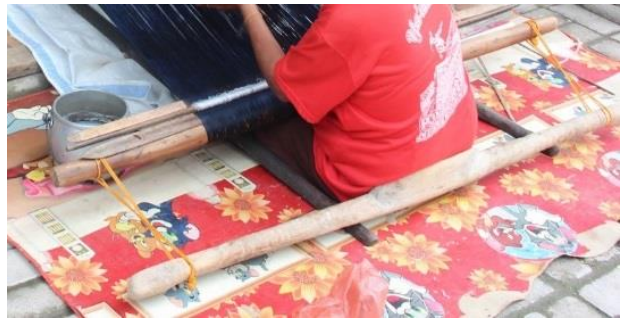

Fig. 9. tundalan (back of weaver) dan pagabe

Baliga. Baliga, The Tool for tightening threads, which are pulled / shifted toward the weaver several times. See in figure 10 .

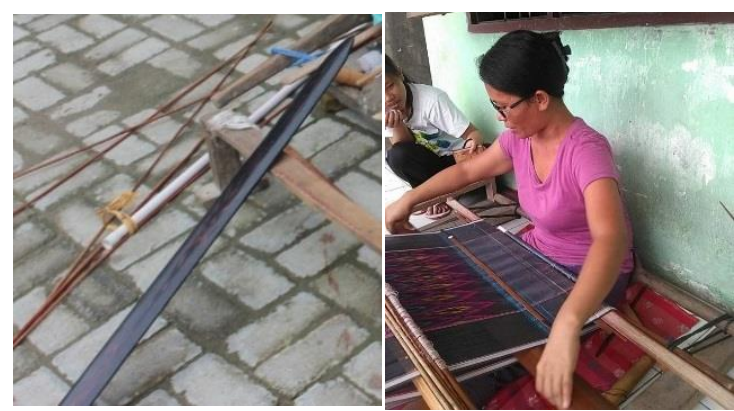

Fig. 10. Baliga dan how to uses 'baliga'

Hasoli. It is thread rolls on sticks, $\pm 20 \mathrm{~cm}$. Feed thread that will be inserted in the warp thread. 
Turak it is the Tool for inserting threads through lungs thread cracks, it made of bamboo, as a container of hasoli.

hasoli

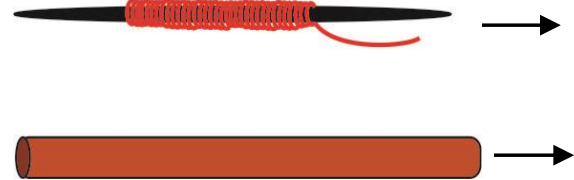

Fig. 11. Hasoli dan Turak

Hatulungan. In figure 12 is Hatulungan. It is a wooden tools for separating threads, usually with the help of nylon threads that have been arranged neatly per sheet of yarn to be woven, loosening the thread so that the turak can enter.

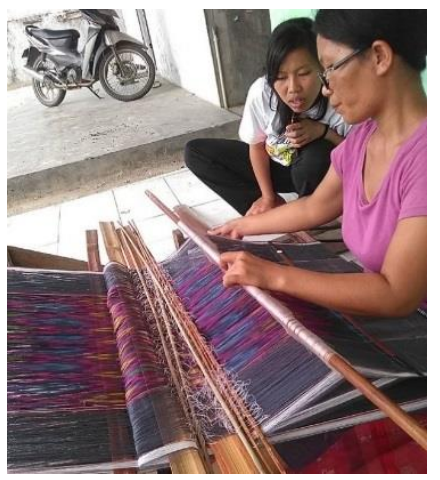

Fig. 12. Hatulungan raised by a weaver

Stick 'Lidi '. Stick, in figure 13. It used for arrange the pattern or color motif of woven fabric. The total of sticks used is based on the ornament to be made. The more complicated the ornament will be as much as the sticks used.

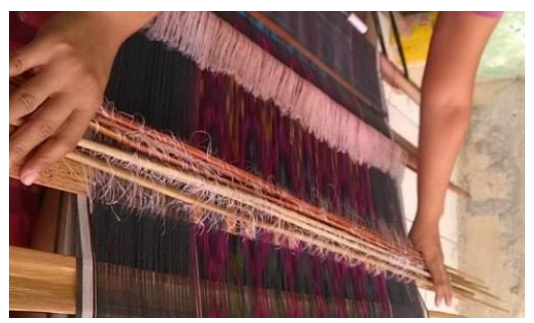

Fig. 13. Lidi

Sokkar / parsokkaran. Figure 14 is a tool for arranging woven patterns / motif. Usually placed on a woven thread.

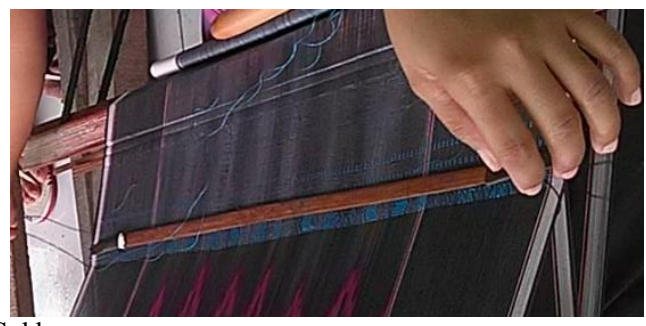

Fig. 14. Sokkar

Sitandakan. In figure 15 is Sitandakan. It is the footstools when weaving, made of wood. The width of this foundation can be adjusted to the height or foot length of the weaver.
Fig. 15. Sitandakan

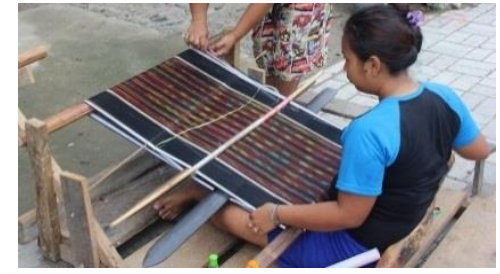

Sidurukan. The pole that is on the right of the weaves. its function is as a base for looms such as pagabe, lidi, etc. See in figure 16.

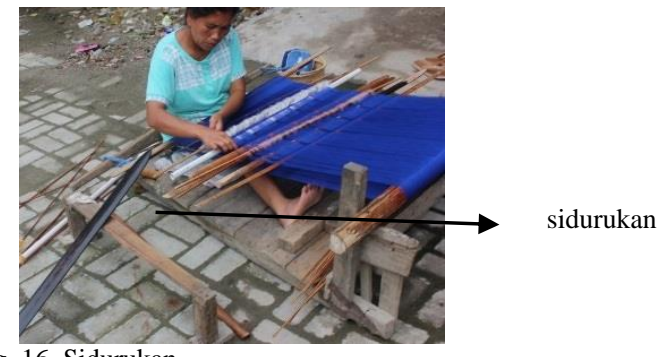

Fig. 16. Sidurukan

\section{The kinds of Ulos Batak Toba and the meaning of ulos Batak}

The Batak Toba is one of the Batak sub-tribes, which consists of Toba, Angkola, Mandailing, Simalungun, Dairi and Karo. Each Batak sub-tribe has a type and characteristic of ulos cloth. The following will explain one type of Ulos that is widely used by the Batak Toba tribe.

In general, the making of ulos is the same, what distinguishes it is name, style or motives, and the nature of their use which must be in accordance with the type of traditional ceremony when give it. however, ulos is always given interpreted and linked to the meaning of symbols. Ulos is considered a concrete medium as an "stamp" so that the application is approved by The One Almighty God [9]. According to the concept of the previous person, weaving has a religious-magical value that must be infused by weavers because there are rules and restrictions that must be fulfilled [10].

At the beginning, the creation of ulos was as a body protector used daily[11]. The ancestors of the Batak people who lived in the mountains must be prepared for the cold weather. At first to protect themselves from cold air is to rely on sunlight, because the sun can not be ruled according to human desires, in the end the previous person turned to fire as a medium of warmth. With all the risks involved in the use of fire, especially when sleeping is considered dangerous. In the end the thought arises to make something that can protect the body by making a piece of cloth as a blanket and protector. In the end it became the forerunner of the creation of ulos as the original fabric of the Batak tribe.

a) Ulos Mangiring is given to the first children, which has meaning so that the children can become role models for their younger siblings and also guide them according to the expectations and tendencies of the Batak tradition. This ulos will become a carry cloth (parompa). 


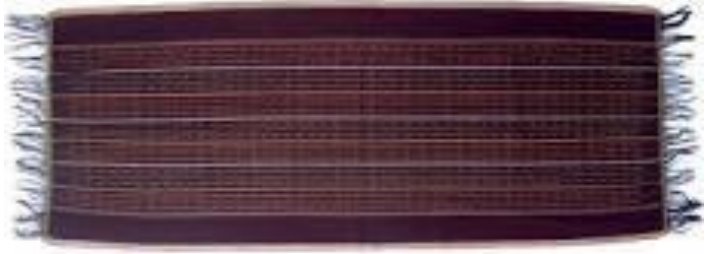

Fig. 17. Ulos Mangiring

Figure was adopted from reference http://www.obatak.id

b) Ulos Sibolang. Including the ulos used in the event of grief (death). That is, the ulos used by adults who have died, who do not have grandchildren, are called Ulos saput. In addition, it is also used by the wife or husband who is left to be called Ulos Tujung.

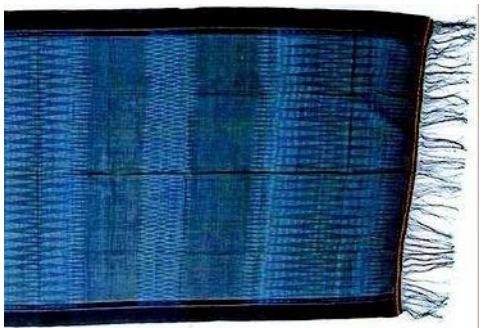

Fig. 18. Ulos Sibolang

Figure was adopted from reference http:// www.pariwisatasumut.net

c) Ulos Ragihotang (Ulos Sirara). Ulos are most often used by the Batak tribe, this ulos usually becomes a bride gift that is holding a traditional Batak wedding ritual. Given by hula-hula (uncle of women) to the hela (son-in-law).

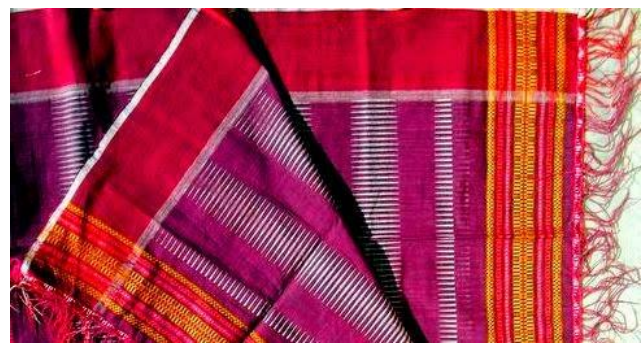

Fig. 19. Ulos Ragihotang

Figure was adopted from reference http:// www.pariwisatasumut.net

d) Pinussaan (Ragi Idup). Used for party events. Ulos which is given to sick people as a hope to be given health. Families entering new homes (usually made custom / thanksgiving events). Hula-hula is given to Boru. Giving parents to male parents. Awarded by grandparents to sons and daughters, as protectors, guardian of sons and daughters to be happy and dignified. It can also be used as a wrapper for the deceased that all children are married.

This Ulos consists of five parts that are woven separately which are then neatly joined together to form one Ulos.

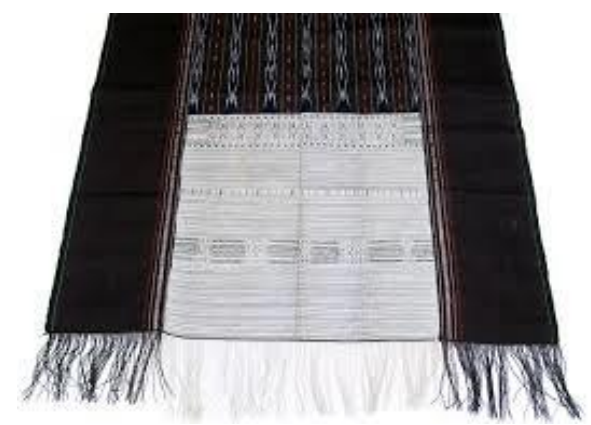

Fig. 20. Ulos Ragi Idup

Figure was adopted from reference http://bins.esy.es

\section{CONCLUSION}

Ulos is not just cloth, but also symbolic at certain moments. In Ulos, there is its own philosophy which contains certain prayers, hopes and meanings. With the rules in giving ulos based on three phases of human life and the situation at that time. In addition to making ulos with weaving machines, there were still weaver who used traditional weaving techniques (gedogan) spread in several regions, especially in North Sumatra Province. Finally, the implementation of customs is still maintained even though there are challenges in the young generation who are affected by changing times and other conditions.

\section{ACKNOWLEDGEMENT}

The research reported here was carried out by the author. Thanks to Dr. Ir. Eddy Soeryanto Soegoto as rector of UNIKOM has supported this seminar event (ICOBEST) and all crew, All informant who has gived many information about Ulos Batak, and then thanks to Prof. Yusuf Affendi Djalari, Dr. Abay D. Subarna and Dr. Yeffry Handoko Putra, M.T as mentor lecturer from UNIKOM who has guided me from beginning to the end that greatly improved the journal.

\section{REFERENCES}

[1] Sachari, Agus.ESTETIKA: Meanings, Symbols and Power. Bandung: ITB Publisher. 2002

[2] Studd, Rachel. "The textile design process." The Design Journal 5.1 (2002) p: 35-49. (references)

[3] Irvan, Muhammad. Thesis: Analysis of Ulos Parompa Judging from the Shape of Ornament, Color, Function and Meaning in Kecamatan Sipirok Kabupaten Tapanuli Selatan. Medan : Medan State University.2016 in digilib.unimed.ac.id

[4] Aprilia, Vivi. Thesis: The symbolic meaning of cultural communication in the marriage ceremony of the Toba Batak community in Pekanbaru. Pekanbaru: University of Pekanbaru.2016 in https://media.neliti.com

[5] Situmorang, Yose Julius. Journal : Semiotics Analysis On Color Symbols In Tobanese Batak Ulos. Medan : HKBP Nomensen University.2016 In https://uhn.ac.id

[6] Takari, Muhammad. Journal : Ulos and of a kind in Bataknese culture north Sumatera : meanings, Functions and technology for the Nusantara Weaving International Seminar in Kuantan, Pahang, Malaysia. Medan : North Sumatera University. 2009 in https://www.etnomusikologiusu.com/uploads/1/8/0/0/1800340/takariul os.pdf

[7] Dakung, Sugiarto, Drs. Ulos: Cultural Media Project. Jakarta: Directorate General of Culture, Ministry of Education and Culture.1982

[8] Poedjawijatna, I.R. Human and Nature.Jakarta:Bina Aksara.1987

[9] Pardosi, Jhonson. "The Symbolic Meanings of Umpasa, Sinamot, and Ulos in the Traditional Toba Batak Marriage." Symbolic Meanings of 
Umpasa, Sinamot, and Ulos in the Toba Batak Marriage Tradition. Accent journal volume 4.2008

[10] Vergouwen, Jacob Cornelis. Community and Toba Batak customary law. LKis Pelangi Aksara, 2004.

[11] Lestari, Titit. Knowing Ulos. Banda Aceh: National History and Value Publishing Center.2010 